\title{
STUDI DESKRIPTIF IMPLEMENTASI KURIKULUM 2013 PADA MATA PELAJARAN MATEMATIKA DI SMPN 1 CIKULUR
}

\author{
Tonnie Hari Nugraha \\ SMP Negeri 1 Cikulur \\ tonniehn@gmail.com
}

\begin{abstract}
ABSTRAK
Penelitian ini bertujuan untuk mendeskripsikan dan menggambarkan implementasi kurikulum 2013 pada mata pelajaran matematika, baik mengenai bahan ajar, pelaksanaan pembelajaran maupun penilaian di SMPN 1 Cikulur. Penelitian ini merupakan penelitian deskriptif dengan pendekatan kualitatif. Subjek dalam penelitian ini sebanyak 3 orang guru mata pelajaran matematika yang mengajar di kelas 7, 8 dan 9 SMPN 1 Cikulur. Instrumen utama pada studi ini adalah peneliti sendiri. Selain itu, ditunjang dengan instrumen pendukung berupa observasi dan wawancara. Data dianalisis secara deskriptif untuk menggambarkan implementasi pelaksanaan kurikulum 2013 pada mata pelajaran matematika. Hasil penelitian diperoleh bahwa: 1) Bahan ajar yang digunakan pada kurikulum 2013 adalah buku guru (BG) dan buku siswa (BS) dengan perbandingan banyaknya siswa dengan buku siswa di SMPN 1 Cikulur adalah 1:1. Secara isi dan materi pada BG dan BS sudah sesuai dengan apa yang diamanatkan oleh kurikulum 2013 revisi 2017 , 2) Pendekatan saintifik sudah mulai terbiasa dilakukan dalam pembelajaran matematika di SMPN 1 Cikulur. Agar model-model pembelajaran yang lain biasa diterapkan di SMPN 1 Cikulur dilakukan dengan kegiatan MGMP Matematika, 3) Pengolahan nilai dan pengisian laporan hasil belajar siswa lebih rumit dibanding dengan kurikulum sebelumnya. Untuk mempermudah dan penyeragamanan dalam pengisian laporan hasil belajar siswa dengan menggunakan aplikasi eraport. Guru SMPN 1 Cikulur belum semuanya menguasai ICT. Untuk mengatasi hal tersebut pihak sekolah mengadakan sosialisasi dan kegiatan IHT tentang pengisian e-rapot dan memfasilitasi semua sarana dan prasarana yang berhubungan dengan e-raport.
\end{abstract}

Kata Kunci: implementasi kurikulum 2013, matematika.

\begin{abstract}
This study aims to describe and describe the implementation of the 2013 curriculum on mathematics subjects, both regarding teaching materials, the implementation of learning and assessment at SMP 1 Cikulur. This research is a descriptive study with a qualitative approach. Subjects in this study were 3 math teachers who taught in grades 7, 8 and 9 of SMPN 1 Cikulur 1. The main instrument in this study is the researchers themselves. In addition, it is supported by supporting instruments in the form of observation and interviews. Data were analyzed descriptively to illustrate the implementation of the 2013 curriculum on mathematics subjects. The results showed that: 1) Teaching materials used in the 2013 curriculum were teacher books (BG) and student books (BS) with a comparison of the number of students with student books at SMPN 1 Cikulur was 1: 1. The content and material in BG and BS are in accordance with what is mandated by the 2013 revised curriculum in 2017,2) The scientific approach has become accustomed to being done in mathematics learning at SMPN 1 Cikulur. In order for other learning models to be applied at SMPN 1 Cikulur, the Mathematics MGMP activities were conducted, 3) Processing the value and filling in student learning outcomes reports are more complicated than the previous curriculum. To simplify and simplify the filling in student learning outcomes reports using the ereport application. SMPN 1 Cikulur teacher has not all mastered ICT. To overcome this, the school
\end{abstract}


held socialization and IHT activities on e-report filling and facilitated all facilities and infrastructure related to e-report.

Keywords: implementation of the 2013 curriculum, mathematics.

\section{PENDAHULUAN}

Terdapat dua dimensi dalam kurikulum, yaitu: 1) rencana dan pengaturan tentang tujuan, isi, dan bahan pelajaran, 2) cara yang digunakan dalam kegiatan pembelajaran. Kurikulum senantiasa berkembang secara dinamis sesuai dengan tuntutan perkembangan jaman. Kaitannya dengan perubahan kurikulum, Soetopo dan Soemanto (1991) menyatakan bahwa suatu kurikulum disebut mengalami perubahan bila terdapat adanya perbedaan dalam satu atau lebih komponen kurikulum antara dua periode tertentu, yang disebabkan oleh adanya usaha yang disengaja.

Pengembangan Kurikulum 2013 merupakan langkah lanjutan pengembangan Kurikulum Berbasis Kompetensi (KBK) yang telah dirintis pada tahun 2004 dan Kurikulum 2006. Dalam kerangka pengembangan kurikulum 2013, hanya empat standar yang berubah, yakni Standar Kompetensi Lulusan (SKL), Standar Proses, Standar Isi, dan Standar Penilaian. Standar Kompetensi Lulusan adalah kriteria mengenai kualifikasi kemampuan lulusan yang mencakup sikap, pengetahuan, dan keterampilan. Standar Isi adalah kriteria mengenai ruang lingkup materi dan tingkat kompetensi untuk mencapai kompetensi lulusan pada jenjang dan jenis pendidikan tertentu. Standar Proses adalah kriteria mengenai pelaksanaan pembelajaran pada satu satuan pendidikan untuk mencapai SKL. Standar Penilaian Pendidikan adalah kriteria mengenai mekanisme, prosedur, dan instrumen penilaian hasil belajar peserta didik.

Kurikulum 2013 dikembangkan berdasarkan rasional tantangan internal dan eksternal. Tantangan internal, antara lain terkait dengan kondisi pendidikan dengan tuntutan pendidikan yang mengacu kepada delapan Standar Nasional Pendidikan yang meliputi standar isi, standar proses, standar kompetensi lulusan, standar pendidik dan tenaga kependidikan, standar sarana dan prasarana, standar pengelolaan, standar pembiayaan, dan standar penilaian pendidikan. Sedangkan tantangan eksternal, antara lain terkait dengan arus globalisasi dan berbagai isu pendidikan. pergeseran kekuatan ekonomi dunia, pengaruh dan imbas teknosains serta mutu, investasi, dan transformasi bidang pendidikan. Keikutsertaan Indonesia di dalam studi International Trends in International Mathematics and Science Study (TIMSS) dan Program for International Student Assessment (PISA) sejak tahun 1999 juga menunjukkan bahwa capaian anak-anak 
$\overline{\text { Indonesia tidak menggembirakan. Hal ini antara lain dikarenakan banyak materi uji yang }}$ ditanyakan tidak terdapat dalam kurikulum Indonesia.

Kurikulum 2013 mengalami beberapa perkembangan dan perbaikan sejak digulirkannya pada tahun 2013. Secara umum, perbaikan Kurikulum 2013 bertujuan agar selaras antara ide, desain, dokumen, dan pelaksanaannya. Secara khusus, perbaikan Kurikulum 2013 bertujuan menyelaraskan KI-KD, silabus, pedoman mata pelajaran, pembelajaran, penilaian, dan buku teks.

Kurikulum 2013 pertama kali diterapkan di SMPN 1 Cikulur pada tahun 2014, dan hanya diberlakukan untuk kelas 7 saja. Berdasarkan instruksi dari kementrian setelah 1,5 tahun diterapkan di kelas 7 dan 8, kurikulum 2013 diberhentikan sementara untuk diperbaiki karena banyak hal yang merasa belum siap. Dengan demikian semua tingkatan kembali lagi menggunakan kurikulum 2006 sambil menunggu perbaikan dan pengembangan kurikulum 2013 oleh pemerintah.

Untuk mempersiapkan pemberlakuan kurikulum 2013, banyak hal yang dilakukan oleh pemerintah baik dari peraturan, bahan ajar maupun sumber daya manusianya agar kurikulum 2013 benar-benar siap digunakan. Dari sumber daya manusia, khususnya guru, dilaksanakan pelatihan-pelatihan, mulai dari pelatihan untuk Instruktur Nasional (IN), Instruktur Propinsi (IP) dan Instruktur Kabupaten (IK). Mereka menjadi ujung tombak untuk menyampaikan dan mendampingi guru-guru sekolah yang menjadi sasaran pemberlakuan kurikulum 2013. Bahan ajar untuk buku direvisi supaya lebih sesuai dengan keadaan. Peraturan-peraturan terkait Standar Isi, Standar Proses, Kompetensi Inti dan Kompetensi Dasar (KI-KD) dan Standar Penilaian diubah untuk memperbaiki peraturan sebelumnya.

Sekolah-sekolah yang ditunjuk untuk melaksanakan kurikulum 2013 dilakukan secara bertahap selama tiga tahun. Penentuan sekolah yang melaksanakan kurikulum 2013 tergantung dari akreditasi sekolah yang dilakukan oleh BAN-SMP. Karena SMPN 1 Cikulur berakreditasi B, maka SMPN 1 Cikulur melaksanakan kurikulum 2013 pada tahap pertama di tahun 2016, dan hanya untuk kelas 7, tahun berikutnya kelas 7 dan 8 dan seterusnya.

Setelah hampir tiga tahun pemberlakuan kurikulum 2013 di SMPN 1 Cikulur, sudah banyak hal yang dipahami oleh sebagian besar guru dalam pembelajaran. Baik dalam penyusunan perangkat pembelajaran, pelaksanaan pembelajaran dan penilaian hasil belajar. Namun demikian, masih ada beberapa kendala yang sering dialami dalam 
pelaksanaannya, tetapi hal itu dapat teratasi dengan seringnya diskusi antara guru, salah satunya dengan kegiatan Musyawarah Guru Mata Pelajaran (MGMP).

Kurikulum 2013 (Kemdikbud, 2016a) dirancang dengan enam karakteristik, yaitu: 1) mengembangkan keseimbangan antara sikap spiritual dan sosial, pengetahuan dan keterampilan, serta menerapkannya dalam berbagai situasi di sekolah dan masyarakat; 2) menempatkan sekolah sebagai bagian dari masyarakat yang memberikan pengalaman belajar agar peserta didik mampu menerapkan apa yang dipelajari di sekolah ke masyarakat dan memanfaatkan masyarakat sebagai sumber belajar; 3) memberi waktu yang cukup leluasa untuk mengembangkan berbagai sikap, pengetahuan, dan keterampilan; 4) mengembangkan kompetensi yang dinyatakan dalam bentuk kompetensi inti kelas yang dirinci lebih lanjut dalam kompetensi dasar mata pelajaran; 5) mengembangkan kompetensi inti kelas menjadi unsur pengorganisasi (organizing elements) kompetensi dasar; 6) mengembangkan kompetensi dasar berdasar pada prinsip akumulatif, saling memperkuat (reinforced) dan memperkaya (enriched) antar-mata pelajaran dan jenjang pendidikan (organisasi horizontal dan vertikal).

Dalam kurikulum 2013, proses pembelajaran menggunakan pendekatan saintifik, yaitu pembelajaran yang mendorong siswa lebih mampu dalam mengamati, menanya, mengumpulkan informasi, mengasosiasi/menalar, dan mengomunikasikan. Hasil akhirnya adalah peningkatan dan keseimbangan antara soft skills serta hard skills siswa yang meliputi aspek kompetensi sikap, keterampilan, dan pengetahuan. Model pembelajaran yang diperlukan adalah yang memungkinkan terbudayakannya kecapakan berpikir sains, terkembangkannya "sense of inquiry" dan kemampuan berpikir kreatif siswa. Model pembelajaran harus mampu menghasilkan kemampuan untuk belajar, bukan saja diperolehnya sejumlah pengetahuan, keterampilan, dan sikap, tetapi yang lebih penting adalah bagaimana hal itu diperoleh siswa.

Penguatan materi pada Kurikulum 2013 dilakukan dengan pengurangan materi yang tidak relevan serta pendalaman dan perluasan materi yang relevan bagi peserta didik. Juga menambahkan materi yang dianggap penting dalam perbandingan internasional, serta penguatan tujuan pembelajaran yang ingin dicapai. Cakupan materi di SMP untuk mata pelajaran matematika meliputi bilangan rasional, real, pengenalan aljabar, himpunan, geometri dan pengukuran (termasuk transformasi, bangun tidak beraturan), dan statistika dan peluang (termasuk metode statistik sederhana).

Pada tahun 2016, kurikulum 2013 mengalami perbaikan (Kemdikbud, 2016b). Perbaikan tersebut dilaksanakan berdasarkan prinsip perbaikan kurikulum sebagai berikut: 
1) keselarasan, antara dokumen KI-KD, silabus, pedoman mata pelajaran, buku teks pelajaran, pembelajaran, dan penilaian hasil belajar harus selaras dari aspek kompetensi dan lingkup materi; 2) mudah dipelajar, lingkup kompetensi dan materi yang dirumuskan dalam KD mudah dipelajari oleh peserta didik sesuai dengan tingkat perkembangan psikologis dan aspek pedagogis; 3) mudah diajarkan, lingkup kompetensi dan materi yang dirumuskan pada KD mudah diajarkan oleh guru sesuai dengan gaya belajar peserta didik, karakteristik mata pelajaran, karakteristik kompetensi, dan sumber belajar yang ada di lingkungan; 4) terukur, kompetensi dan materi yang diajarkan terukur melalui indikator yang mudah dirumuskan dan layak dilaksanakan; 5) bermakna untuk dipelajari, kompetensi dan materi yang diajarkan mempunyai kebermaknaan bagi peserta didik sebagai bekal kehidupan.

Sementara kebijakan mengenai buku teks pelajaran untuk kurikulum 2013 pada tahun 2016 ini, diantaranya bahwa buku lama Kurikulum 2013 tetap dapat dipergunakan sebagai sumber belajar dan buku teks pelajaran dari pemerintah bukan satu-satunya sumber belajar utama. Penerbitan buku teks pelajaran dapat dilakukan oleh kemdikbud atau swasta dengan ketentuan (Mendikbud, 2016) sebagai berikut: 1) buku teks pelajaran harus memuat aktivitas untuk peserta didik yang digunakan dalam proses pembelajaran; 2) pelaku penerbitan terdiri atas penulis, editor, ilustrator, penelaah, konsultan, reviewer, penilai, dan/atau penerbit, informasi pelaku penerbitan wajib dimuat pada bagian akhir buku; 3) satuan pendidikan wajib memilih dan menyediakan buku teks pelajaran yang dinyatakan layak dan wajib mengevaluasi seluruh buku yang digunakan oleh satuan pendidikan; 4) penilaian kelayakan buku diajukan oleh penerbit kepada Kemdikbud atau BSNP.

Pada tahun 2017, kurikulum 2013 kembali direvisi terutama pada tiga hal yang akan dicapai kurikulum, yaitu karakter, kompetensi dan literasi. Kualitas karakter untuk menghadapi lingkungan yang terus berubah adalah iman dan taqwa cinta tanah air, rasa ingin tahu, inisiatif, gigih, kemampuan beradaptasi, kepemimpinan dan kesadaran sosial dan budaya. Sedangkan kompetensi untuk mengatasi tantangan kompleks adalah berpikir kritis/memecahkan masalah, kreativitas, komunikasi dan kolaborasi. Dan literasi untuk menerapkan keterampilan inti dalam kehidupan sehari-hari diantaranya: baca tulis, berhitung, literasi sains, literasi informasi teknologi dan komunikasi.

Berdasarkan uraian di atas, tujuan dari penelitian ini adalah untuk mengetahui sejauh mana persepsi guru matematika terhadap implementasi kurikulum 2013 di SMPN 1 
Cikulur terkait bahan ajar, pelaksanaan pembelajaran dan penilaian hasil belajar siswa dalam belajar matematika.

\section{METODE PENELITIAN}

Jenis penelitian yang digunakan dalam penelitian ini adalah deskriptif dengan pendekatan kualitatif. Penelitian deskriptif merupakan penelitian yang dimaksudkan untuk mengumpullkan informasi mengenai status suatu gejala yang ada, yaitu keadaan gejala menurut apa adanya pada saat penelitian dilakukan. Penelitian deskriptif menggambarkan apa adanya tentang suatu variabel, gejala atau keadaan (Arikunto, 2000). Pendekatan yang digunakan dalam penelitian ini adalah pendekatan kualititatif.

Penelitian ini dilakukan untuk mendeskripsikan dan menggambarkan implementasi kurikulum 2013 pada mata pelajaran matematika baik mengenai bahan ajar, pelaksanaan pembelajaran dan penilaiannya di SMP Negeri 1 Cikulur. Daerah penelitian dalam penelitian ini adalah SMP Negeri 1 Cikulur, sedangkan subjek penelitian adalah guru mata pelajaran matematika yang mengajar di kelas 7, 8 dan 9 sebanyak 3 orang di SMPN 1 Cikulur.

Instrumen utama pada studi ini adalah peneliti sendiri. Selain itu, ditunjang dengan instrumen pendukung berupa observasi dan wawancara. Metode observasi dilakukan dengan cara mengamati bukti fisik yang ada sekolah seperti profil sekolah, dokumen kurikulum, dokumen penilaian, kegiatan-kegiatan yang berhubungan dengan kurikulum 2013, dan juga proses kegiatan belajar mengajar di SMP Negeri 1 Cikulur sepeti perangkat dan pelaksanaan pembelajaran di kelas serta sarana prasarana yang ada. Adapun secara garis besar butir-butir wawancara yang berhubungan dengan implementasi Kurikulum 2013, yaitu mengenai awal penerapan Kurikulum 2013, bahan ajar, pelaksanaan pembelajaran dan penilaian hasil belajar matematika menggunakan Kurikulum 2013 di sekolah.

\section{HASIL DAN PEMBAHASAN}

\section{Awal Penerapan Kurikulum 2013}

Implementasi Kurikulum 2013 pertama kali dilaksanakan pada tahun 2014 untuk beberapa sekolah yang menjadi sasaran. Salah satu sekolah yang ditunjuk adalah SMPN 1 Cikulur dan hanya diberlakukan untuk kelas 7 saja. Kemudian pada akhir tahun 2015, kurikulum 2013 dihentikan sementara untuk perbaikan dan penyempurnaan. Semua sekolah kembali memberlakukan Kurikulum 2006 (KBK). 
Implementasi Kurikulum 2013 kembali dilaksanakan pada tahun 2016. Sekolahsekolah yang ditunjuk untuk melaksanakan kurikulum 2013 dilakukan secara bertahap selama tiga tahun. Penentuan sekolah yang melaksanakan kurikulum 2013 tergantung dari akreditasi sekolah yang dilakukan oleh BAN-SMP. SMPN 1 Cikulur merupakan salah satu sekolah yang ditunjuk untuk melaksanakan Kurikulum 2013 pada tahap pertama karena berdasarkan akreditasi BAN-SMP berkategori B. Implementasi Kurikulum 2013 pada tahun 2016 di SMPN 1 Cikulur hanya dilaksanakan untuk kelas 7 saja dan berlanjut untuk tahun berikutnya, sehingga pada tahun 2018 semua jenjang kelas 7, 8 dan 9 sudah melaksanakannya.

Untuk mempersiapkan pemberlakuan kurikulum 2013, banyak hal yang dilakukan oleh pemerintah maupun pihak sekolah. Sebelum tahun pelajaran 2016/2017 dimulai, semua guru mata pelajaran yang mengajar di kelas 7 diikutsertakan dalam pelatihan guru sasaran (GS) yang diselenggarakan oleh LPMP Propinsi Banten. Pelatihan ini dilaksanakan untuk menganalisis tentang KI-KD dan bahan ajar (buku guru dan buku siswa), mendiskusikan tentang penyusunan perangkat pembelajaran, pelaksanaan pembelajaran yang menjadi ciri khas dikurikulum 2013, dan penilaian sampai membuat laporan hasil belajar siswa, serta hal-hal yang berhubungan dengan implementasi kurikulum 2013.

Tindak lanjut dari pelatihan tersebut adalah dilaksanakannya pendampingan bagi semua guru sasaran pada saat mengimplementasikan di SMPN 1 Cikulur. Dengan diadakannya pendampingan ini diharapkan dapat terlihat hal-hal yang menjadi hambatan dan kendala dalam implementasi kurikulum 2013 dan dapat menemukan solusinya. Disamping itu juga untuk melihat sampai sejauh mana ketercapaian pelaksanaan kurikulum 2013 di SMPN 1 Cikulur.

\section{Bahan Ajar Kurikulum 2013}

Bahan ajar yang digunakan pada kurikulum 2013 adalah buku guru (BG) dan buku siswa (BS). BG dan BS dikeluarkan oleh pemerintah dan satu-satunya bahan ajar yang digunakan oleh sekolah yang menerapkan kurikulum 2013 pada tahun 2014. Untuk memperoleh $\mathrm{BG}$ dan $\mathrm{BS}$, sekolah dapat memesan kepada rekanan yang ditunjuk oleh pemerintah dengan harga yang sudah ditentukan. BS dapat digunakan oleh siswa dalam pembelajaran di sekolah maupun di rumah. Perbandingan banyaknya siswa dengan buku siswa di SMPN 1 Cikulur adalah 1:1, sesuai dengan standar yang sudah ditentukan.

Kurikulum 2013 mengalami revisi pada tahun 2016, salah satu perubahannya adalah BG dan BS bukan satu-satunya bahan ajar yang digunakan oleh sekolah. Pihak 
sekolah bisa menggunakan bahan ajar lain yang relevan dengan BG dan BS yang dikeluarkan oleh pemerintah. Selain itu, BG dan BS yang sudah dikeluarkan oleh pemerintah tahun 2014 masih dapat digunakan pada kurikulum 2013 revisi tahun 2016, meskipun banyak revisi berkaitan dengan kompetensi dasar, materi dan penilaian. Namun secara garis besar tidak jauh berbeda dari yang sebelumnya.

Pada revisi kurikulum 2013 berikutnya tahun 2017, pemerintah mewajibkan sekolah untuk menyediakan BG dan BS yang anggarannya diambil sebanyak $20 \%$ dari dana BOS (Bantuan Operasional Sekolah) pada triwulan ke-3. Sekolah harus sudah menyediakan BG dan BS sebelum tahun pelajaran baru dilaksanakan, sehingga diharapkan BG dan BS dapat digunakan pada awal tahun pelajaran.

Secara isi dan materi pada BG dan BS sudah sesuai dengan apa yang diamanatkan oleh kurikulum 2013 revisi 2017. Walaupun masih ada kekurangan dalam beberapa materi dan keluhan dari guru SMPN 1 Cikulur untuk menyampaikan kepada siswa terkait ketersesuaian dengan karakter dan penerapan dalam kehidupan sehari-hari dilingkungan SMPN 1 Cikulur.

\section{Pelaksanaan Pembelajaran Kurikulum 2013}

Sejalan dengan konsep dasar dan prinsip-prinsip pembelajaran tersebut, pembelajaran pada Kurikulum 2013 menggunakan pendekatan saintifik atau pendekatan berbasis proses keilmuan. Pendekatan saintifik dapat menggunakan beberapa strategi seperti pembelajaran kontekstual. Pembelajaran dengan pendekatan saintifik terdiri atas lima langkah kegiatan belajar yakni mengamati (observing), menanya (questioning), mengumpulkan informasi/mencoba (experimenting), menalar atau mengasosiasi (associating), mengomunikasikan (communicating) yang dapat dilanjutkan dengan mencipta. Langkah-langkah pembelajaran dengan pendekatan saintifik tersebut mengikuti langkah-langkah pada metode ilmiah.

Selain itu dapat diterapkan model-model pembelajaran lainnya, antara lain discovery learning, project-based learning, problem-based learning, inquiry learning (Kemdikbud, 2016b). Pembelajaran penemuan (discovery learning) adalah pembelajaran untuk menemukan konsep, makna, dan hubungan kausal melalui pengorganisasian pembelajaran yang dilakukan oleh peserta didik. Tiga ciri utama belajar menemukan yaitu: (1) mengeksplorasi dan memecahkan masalah untuk menciptakan, menggabungkan dan menggeneralisasi pengetahuan; (2) berpusat pada peserta didik; (3) kegiatan untuk menggabungkan pengetahuan baru dan pengetahuan yang sudah ada. 
Pembelajaran berbasis proyek (project-based learning) adalah kegiatan pembelajaran yang menggunakan proyek/kegiatan sebagai proses pembelajaran untuk mencapai kompetensi sikap, pengetahuan dan ketrampilan. Penekanan pembelajaran terletak pada aktivitas-aktivias peserta didik untuk menghasilkan produk dengan menerapkan keterampilan meneliti, menganalisis, membuat, sampai dengan mempresentasikan produk pembelajaran berdasarkan pengalaman nyata. Produk yang dimaksud adalah hasil Proyek dalam bentuk desain, skema, karya tulis, karya seni, karya teknologi/prakarya, dan lain-lain. Pendekatan ini memperkenankan pesera didik untuk bekerja secara mandiri maupun berkelompok dalam menghasilkan produk nyata.

Pembelajaran berbasis masalah (problem-based learning) adalah pembelajaran yang menggunakan masalah nyata dalam kehidupan sehari-hari (otentik) yang bersifat terbuka (open-ended) untuk diselesaikan oleh peserta didik untuk mengembangkan keterampilan berpikir, keterampilan menyelesaikan masalah, keterampilan sosial, keterampilan untuk belajar mandiri, dan membangun atau memperoleh pengetahuan baru. Pembelajaran ini berbeda dengan pembelajaran konvensional yang jarang menggunakan masalah nyata atau menggunakan masalah nyata hanya di tahap akhir pembelajaran sebagai penerapan dari pengetahuan yang telah dipelajari. Pemilihan masalah nyata tersebut dilakukan atas pertimbangan kesesuaiannya dengan pencapaian kompetensi dasar.

Pembelajaran inkuiri (inquiry learning) adalah pembelajaran yang melibatkan secara maksimal seluruh kemampuan yang meliputi sikap, pengetahuan, dan keterampilan peserta didik untuk mencari dan menyelidiki sesuatu(benda, manusiaatau peristiwa), secara sistematis, kritis, logis, dan analitis. Karakteristik dari pembelajaran inkuiri adalah menekankan kepada proses mencari dan menemukan, pengetahuan dibangun oleh peserta didik melalui proses pencarian, peran guru sebagai fasilitator dan pembimbing peserta didik dalam belajar, dan menekankan pada proses berpikir kritis dan analitis untuk merumuskan kesimpulan.

Pada pelaksanaan pembelajaran matematika di SMPN 1 Cikulur, masih banyak kesulitan dalam menerapkan model-model pembelajaran tersebut sehingga tidak semua model yang dianjurkan pada kurikulum 2013 digunakan dalam pembelajaran di kelas. Ini disebabkan karena pengetahuan dari guru tentang model-model tersebut dan karakter dari siswa yang belum terbiasa dengan model-model tersebut. Hanya pendekatan saintifik saja yang sudah mulai terbiasa dilakukan dalam pembelajaran matematika di SMPN 1 Cikulur. Namun demikian, seiring waktu berjalan, pihak sekolah berusaha agar semua model-model pembelajaran dapat dibiasakan sehingga hasil pembelajaran bisa tercapai sesuai dengan 
kurikulum 2013. Salah satunya dengan memperbanyak diskusi dan berbagi pengalaman pada kegiatan MGMP Matematika.

\section{Penilaian Hasil Belajar Siswa}

Penilaian hasil belajar pada kurikulum 2013 menekankan pada tiga aspek, yaitu aspek sikap (spiritual dan sosial), pengetahuan dan keterampilan, berbeda dengan kurikulum sebelumnya yang cenderung hanya menekankan aspek pengetahuan saja. Akibatnya aktivitas guru dalam penilaian lebih banyak lagi. Dalam setiap aspek, banyak teknik yang harus dilakukan dan format yang diisi oleh guru baik ketika pembelajaran tatap muka di kelas maupun ketika berada di luar kelas, sehingga guru disibukkan dengan kegiatan penilaian. Disamping itu, dalam pengolahan nilai dan pengisian laporan hasil belajar siswa lebih rumit dibanding dengan kurikulum sebelumnya. Ini menjadi kendala pada pemberlakuan kurikulum 2013 pertama kali digulirkan tahun 2014. Untuk mengatasi semua itu, pihak sekolah membuat aplikasi yang dapat membantu guru dalam proses penilaian tersebut. Tampilan dari aplikasi penilaian hasil belajar yang dibuat oleh sekolah seperti pada Gambar 1.

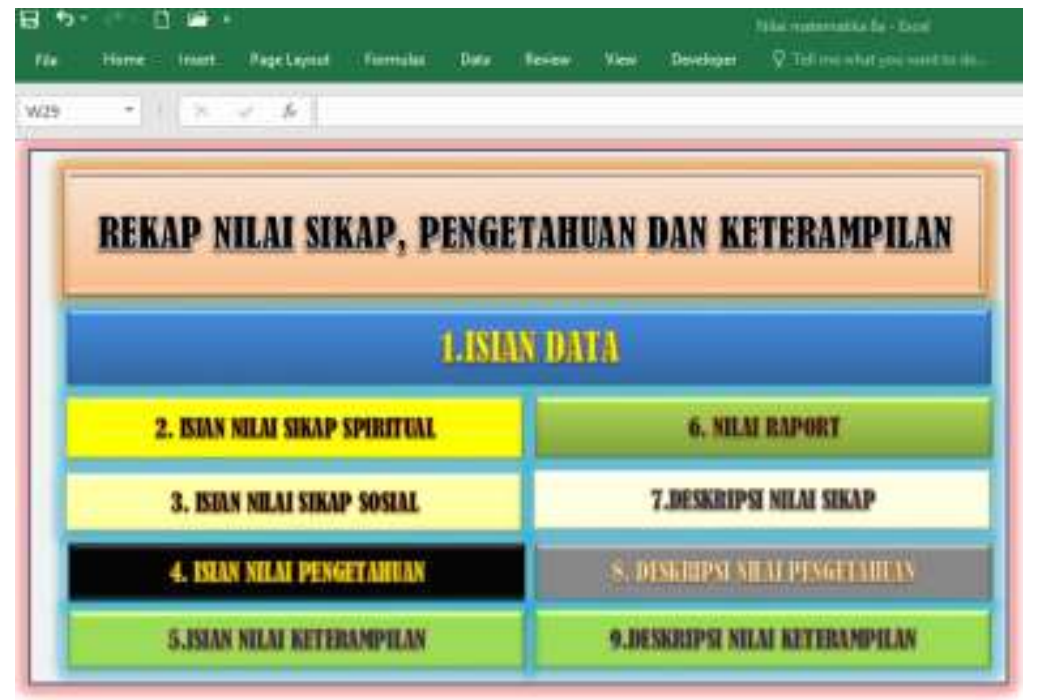

Gambar 1. Tampilan Menu Rekap Nilai Guru Mata Pelajaran

Selanjutnya berikut ini adalah tampilan isian nilai pengetahuan pada Gambar 2. 


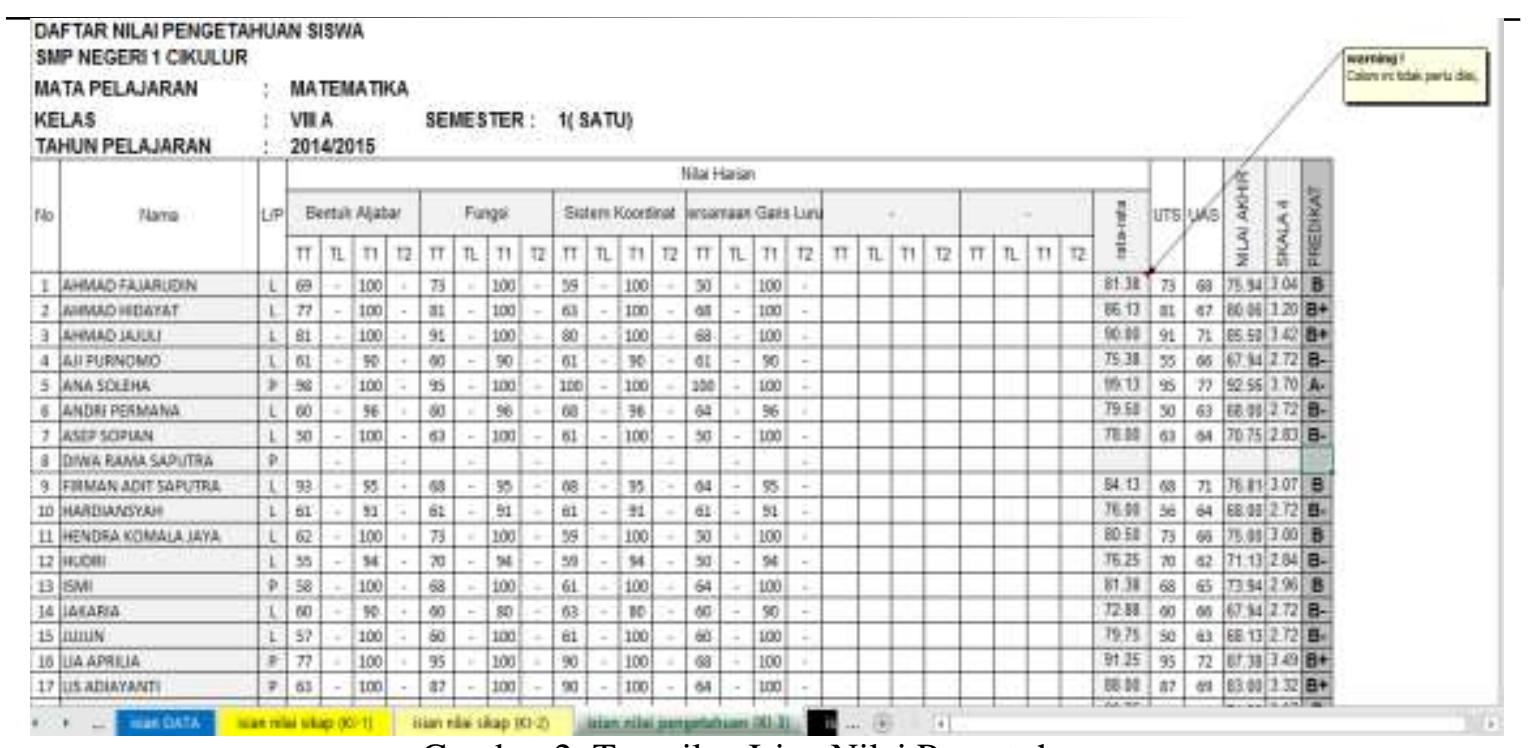

Gambar 2. Tampilan Isian Nilai Pengetahuan

Adapun tampilan menu laporan hasil belajar oleh wali kelas pada Gambar 3.

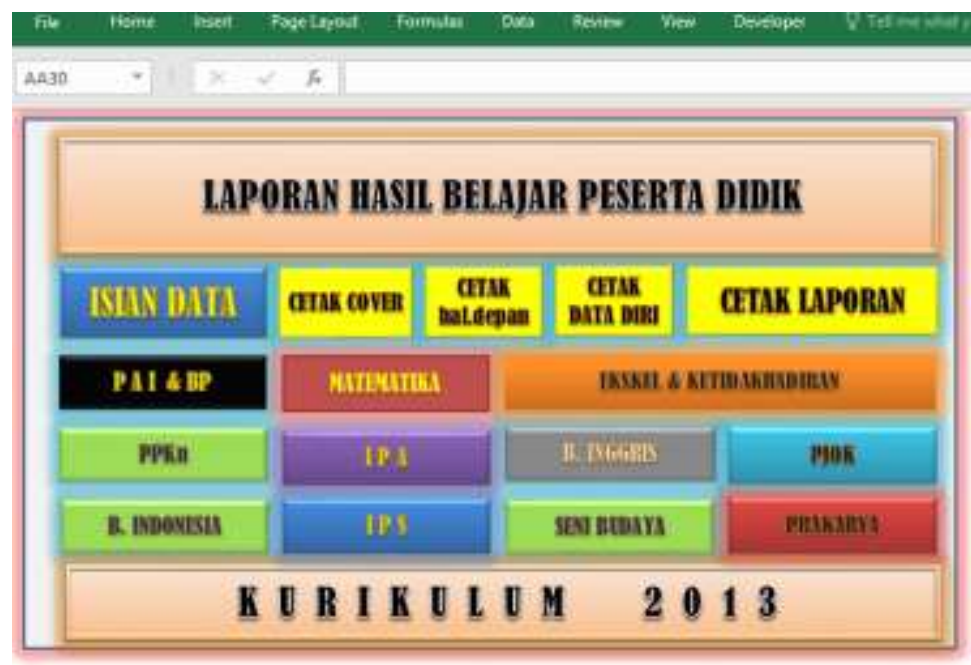

Gambar 3. Tampilan Menu Laporan Hasil Belajar Oleh Wali Kelas

Sosialisasi dan workshop internal sekolah dilakukan, agar semua guru dapat menggunakan dan mempermudah sehingga penilaian hasil belajar siswa dapat dilaksanakan. Melihat banyaknya kendala yang dirasakan dalam penilaian hasil belajar siswa, kurikulum 2013 direvisi pada tahun 2016 termasuk tentang penilaian. Salah satunya adalah menyederhanakan dalam aspek pengetahuan. Tidak semua guru melakukan pembelajaran langsung pada aspek sikap, hanya guru mata pelajaran Pendidikan Agama dan Budi Pekerti pada aspek sikap spiritual dan guru mata pelajaran Pendidikan Pancasila dan Kewarganegaraan pada aspek sikap sosial, sedangkan guru mata pelajaran lain hanya melakukan pembelajaran tidak langsung, tetapi proses penilaian tetap dilaksanakan walaupun dengan teknik dan format yang sederhana.

Untuk mempermudah dan penyeragamanan dalam pengisian laporan hasil belajar siswa, pemerintah meluncurkan aplikasi laporan hasil belajar siswa dalam bentuk 
elektronik yang terhubung dengan Dapodik (Data Pokok Pendidikan) pada tahun 2017. Aplikasi ini disebut dengan e-raport. Berikut tampilan aplikasi e-rapot kurikulum 2013 pada Gambar 4.

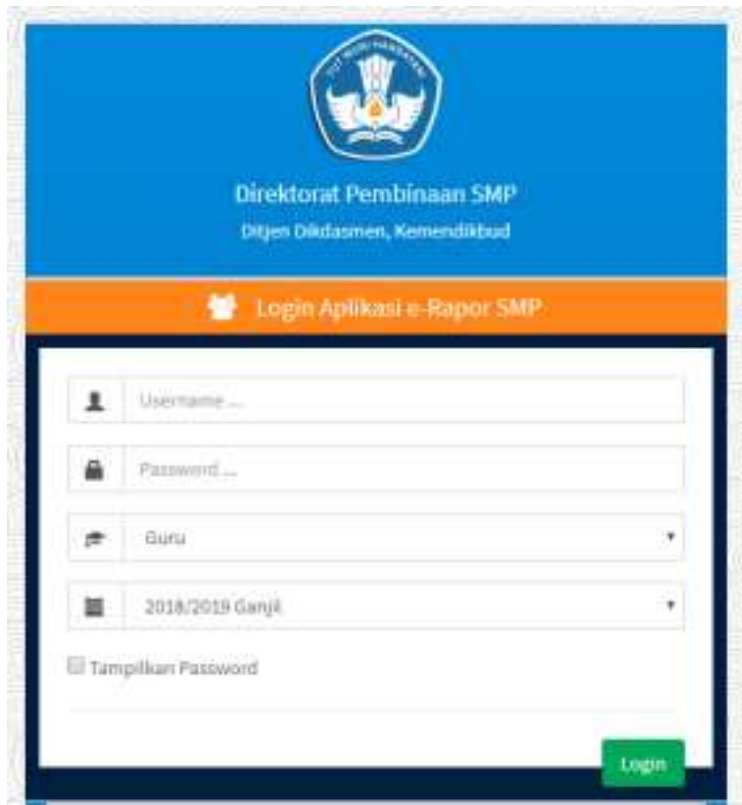

Gambar 4. Tampilan Menu Login E-Rapot

Selanjutnya berikut ini adalah tampilan menu isian untuk guru mata pelajaran pada Gambar 5.

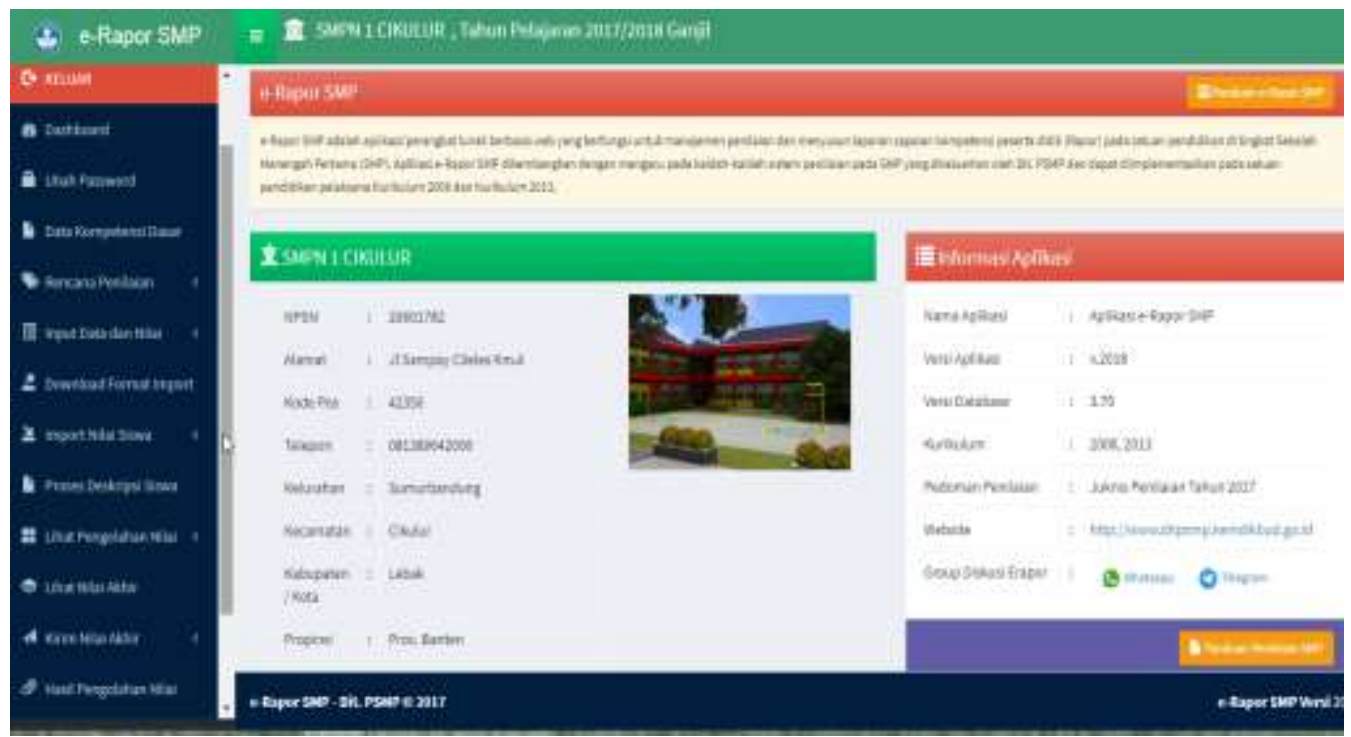

Gambar 5. Tampilan Menu Isian untuk Guru Mata Pelajaran

Dengan e-raport yang terhubung dapodik, semua data baik data guru, siswa mata pelajaran dan lain-lain akan terdata dengan rapih. Banyak kendala yang dirasakan guru SMPN 1 Cikulur diawal kemunculan e-rapot, karena dalam e-rapot ini selain harus mengisi nilai sikap, pengetahuan dan keterampilan juga harus membuat rencana penilaian terlebih dahulu. Selain itu, guru juga harus melek dalam ICT karena e-rapot semuanya berbasis ICT, sedangkan guru di SMPN 1 Cikulur belum semuanya menguasai dalam hal ICT. 
Namun demikian, semua dapat diatasi oleh pihak sekolah dengan diadakannya sosialisasi dan kegiatan IHT tentang pengisian e-rapot dan memfasilitasi semua sarana dan prasarana yang berhubungan dengan e-raport.

\section{KESIMPULAN}

Berdasarkan hasil pembahasan di atas mengenai persepsi guru matematika terhadap implementasi Kurikulum 2013 di SMPN 1 Cikulur terkait bahan ajar, pelaksanaan pembelajaran dan penilaian hasil belajar siswa dalam belajar matematika dapat disimpulkan bahwa buku guru (BG) dan buku siswa (BS) adalah bahan ajar yang resmi digunakan di SMPN 1 Cikulur dengan perbandingan banyaknya siswa dengan buku siswa adalah 1:1, sesuai dengan standar yang sudah ditentukan. BG dan BS dianggarkan sebanyak 20\% dari dana BOS. Secara isi dan materi pada BG dan BS sudah sesuai dengan apa yang diamanatkan oleh kurikulum 2013 revisi 2017.

Untuk pelaksanaan pembelajaran pada Kurikulum 2013, sebagian besar sudah mulai terbiasa menggunakan pendekatan saintifik dalam pembelajaran matematika di SMPN 1 Cikulur. Agar model-model pembelajaran yang lain juga biasa diterapkan di SMPN 1 Cikulur, salah satu upayanya dengan memperbanyak diskusi dan berbagi pengalaman pada kegiatan MGMP Matematika.

Karena pengolahan nilai dan pengisian laporan hasil belajar pada penilaian hasil belajar siswa dikurikulum 2013 lebih rumit dibanding dengan kurikulum sebelumnya maka pemerintah meluncurkan aplikasi laporan hasil belajar siswa dalam bentuk elektronik yang terhubung dengan Dapodik (Data Pokok Pendidikan) yang disebut dengan e-raport. Untuk mengatasi kesulitan guru di SMPN 1 Cikulur yang kurang menguasai ICT maka pihak sekolah mengadakan sosialisasi dan kegiatan IHT tentang pengisian e-rapot dan memfasilitasi semua sarana dan prasarana yang berhubungan dengan e-raport.

\section{REFERENSI}

Arikunto, S. (2000). Manajemen Penelitian. Jakarta: Rineka Cipta.

Kemdikbud. (2016a). Guru Pembelajar Modul Matematika SMP Kelompok Kompetensi D. Jakarta.

Kemdikbud. (2016b). Materi Pelatihan Guru Implementasi Kurikulum 2013 SMP Mata Pelajaran Matematika. Jakarta.

Mendikbud. (2016). Permendikbud No.8 Tahun 2016.

Soetopo, \& Soemanto. (1991). Pembinaan dan Pengembangan Kurikulum Sebagai Substansi Problem Administrasi Pendidikan. Jakarta: Bumi Aksara. 